\title{
Implementation of Omnibus Policy on Kindergarten Education
}

\author{
Marciano Radam Lopez, Jr. ${ }^{1}$, Angelito Estoesta Alvarado ${ }^{2}$ \\ ${ }^{1}$ Faculty, Department of Education, City Schools Division of Dasmariñas, Philippines \\ ${ }^{2}$ Faculty, Isabela State University, Echague Campus, Philippines \\ docgel15@gmail.com²
}

DOI: https://doi.org/10.37134/ajatel.vol10.2.5.2020

Received: 30 April 2020; Accepted: 23 July 2020; Published: 24 July 2020

Cite this article (APA): Alvarado, A. E., \& Lopez, Jr., M. R. (2020). Implementation of Omnibus Policy on kindergarten education. Asian Journal of Assessment in Teaching and Learning, 10(2), 34-54. https://doi.org/10.37134/ajatel.vol10.2.5.2020

\begin{abstract}
The implementation Omnibus Policy on Kindergarten Education was conducted primarily to determine the extent the implementation of the provisions stipulated in the DepEd Order no. 47, series 2016. It serves as the basis for the continuing enhancement in the operation and management of the kindergarten program; a benchmark that will motivate the administrators to initiate continuous improvement on all areas of concerns in the operation of the program as to Instruction, assessment, learning resources, and instructional materials, learning space and environment, and monitoring and evaluation in cluster 2 of the City Schools Division of Dasmarinas, Cavite. The methodology used was a descriptive normative survey through a structured questionnaire which contents were based on the DepEd Order no. 47, series 2016. The nominal data were treated using simple frequency count and percentage distribution, weighted mean was utilized on the areas of implementation in the Omnibus Policy on Kindergarten Education, and Chi-Square was used to test the significant relationship of the demographic profile of the respondents to the implementation of the omnibus policy, whereas ANOVA was used to determine the significant difference between the perception of respondents to the implementation of the Omnibus Policy on Kindergarten Education. Significant results of the study revealed that Assessment, Instruction, and Monitoring and Evaluation got the highest rating as always observed, whereas, Learning resources and instructional materials, and Learning space and environment were felt the same but of lower weighted mean. It is highly remarkable that inadequate play area and equipment found to be the most serious concern in the implementation of the Kindergarten program, and Information and Technology (ICT).
\end{abstract}

Keywords: Kindergarten Education, Implementation, Evaluation

\section{INTRODUCTION}

A strong and solid early foundation in the child's formative years is a key to success in education and life. Theories of human development and researches had conquered and proven that the early childhood years are the most crucial and important periods of development in the physical, mental, emotional, and social aspects of life.

In recent decades, numerous studies have shown that early childhood education is key to success in later school in life. According to Reynolds (2000), long-term effects include a reduction in remediation and assignment to special education, an increase in high school graduation rates, higher rates of employment, and lower instances of crime. Furthermore, children who participate in quality early childhood education "perform better in school, and become productive members of the community and society".

Friedrich Froebel, the founder of kindergarten education has an approach that involves the principles, pedagogy, and environment. As cited by Hermann (1983) the principle takes a holistic view of the individual child's progress and recognizes their uniqueness, capacity, and potential. Froebel also includes that Kindergartens is derived from German which means 'garden for the children' also known 
as Pre-School as he perceived, a child's growth to be like a plant growing and thriving where the right conditions exist.

Pangan (2012) also explained that kindergarten is an educational program designed for young children to prepare them for school. This part of early education for children acts as a transition from home to the school environment. The first six years of a child's life are his most impressionable years (0-6 years), It is the period in which the development and learning of children are at the highest rate. The main goal of preschool education is to improve the physical, cognitive, social, emotional, psychomotor, language, and moral development of children. These areas of development include skills such as self-care, imagination, creativity, analytical thinking, communication, expressing feelings and thoughts in the most accurate way, sharing, responsibility, self-confidence, positive self-development, independent and right decision making, gaining autonomy, sensitivity, scientific thinking. In addition, this is the period when they learn very fast.

Reasons for kindergarten education range from the "promotion of all-round child development to provision of a parking space" for preschool-age children. One of the provisions in the Universal Declaration of Children's Rights states that:

... The child shall enjoy the protection and shall be given opportunities and facilities by law and by other means to enable him to develop physically, mentally, and spiritually in a healthy and normal manner, in a condition of freedom and dignity.

Solis (2012), in an article about Pre-Primary education, wrote that with every favorable environment every year during the first four to six years of life, the development of intelligence has an increase of about 2.5 IQ points, from eight to seventeen years it has only 0.4 points. She said that children with pre-school education tended to retain the additional growth rate they received. Early education and experience have a persistent impact on the child's emotional pattern, his language facilities, his specialization, and his whole personality. She said children best through active involvement in work and play activities. Habits of acceptable behavior, friendly relations, and social skills should be observed during routinary activities. In recent decades, numerous studies have shown that early childhood education is key to success in later school and life. According to Reynolds (2012), long-term effects include a reduction in remediation and assignment to special education, an increase in high school graduation rates, higher rates of employment, and lower instances of crime. Furthermore, children who participate in quality early childhood education "perform better in school, and become productive members of the community and the society" (UNICEF, Philippines).

Baligod (2012) study was about the performance of grade 1 pupils with or without preelementary education. The study found out that pre-elementary education is an early training given to children before they formally enter the first ladder of elementary education. Kindergarten education brings out the child's self- confidence, learn more social skills, and become more comfortable with them. This study pinpoints that parents of children with pre-elementary education have higher educational attainment. Hence, it is concluded that those pupils with pre-elementary education achieve better and have better social and intellectual skills than those without pre-elementary education. Kindergarten is a wonderful experience for children when properly conducted. More so when the emphasis is made on developing a child's physical strength and social skills because this helps them develop self-confidence in going to school. Baligod's study found out that Pre-Elementary education is an early training ground for children before they formally enter this ladder of Elementary Education. This study also emphasizes the kind of program suited for children to enjoy their preschool study through qualified teacher and administrators, standard facilities and equipment and appropriate methods and technique in teaching

Piaget (cited in Wood 2013) believed that all children pass through a series of developmental stages before they construct the ability to perceive reason and understand in mature rational terms. Piaget claimed that the essential nature of human beings was their power to construct knowledge through adaptation to the environment. Thus, through assimilation and accommodation, the child is in a continual process of cognitive self-correction. Equilibration is fundamental to learning as a key contribution to child development is his teaching that learning is a continual process of meaningmaking. 
Children's thinking is embedded in a context that has some meaning to them whereas much school activity ...is 'disembedded' cited by Bautista (2012). Activities such as 'filling in the blanks', worksheets, and 'coloring in' are often removed from meaning and purpose for the child and therefore make the process of learning more difficult. In contrast, first-hand learning experiences fuel children's imagination and an unquenchable thirst for understanding. This type of learning occurs in everyday contexts when children engage in activities that matter to them according to Rich and Drummond (2014), In designing an involvement scale for assessing children's learning and development. Laevers (2010) identified signs of individual active engagement such as concentration, energy, complexity and creativity, facial expression and composure, persistence, precision, reaction time, verbal expression, and satisfaction. Children need to be involved in their learning and it has to be real and meaningful to them.

The United Nations Educational, Scientific and Cultural Organization UNESCO (2006) proposed that the kindergarten curriculum must focus on the following areas: 1.) Physical development: it includes gross and fine motor coordination through play and manipulative activities like games, simple works, etc.; 2.) Personal-social development: it involves skills and social behaviors and it includes the development of healthy habits, independence, abilities to follow rules and routines. Learning about the family and other people is part of the concerns in this area; 3.) Affective development: it includes experiences that help children develop a love for God, self, others, and the community, and develop an awareness of their feelings and sense of the right and wrong; 4.) Cognitive development: it includes the development of communication skills and sensory-perceptual and numeracy concepts and skills. Communication skills refer to competencies in expressing ideas and feelings both in English and Filipino (oral expression and basic readiness skills of listening, pre-reading, and writing). Sensory-perceptual and numeracy skills refer to the ability to observe, discriminate, compare and classify, and to understand, count, read and write numbers; 5.) Creative-aesthetic development: it includes exploration of sounds, music and rhythms, and the development of children's creative expression through drawing, painting, manipulative activities, etc. The abovementioned curriculum was duly adopted by the Department of Education in the Philippines with additional domains of development in the existing $\mathrm{K}$ to 12 curriculum.

According to Estolas and Nunez (2014), an ideal site for an early childhood training center in quiet and spacious providing children with an atmosphere of calmness and a place where they romp around with the least danger of unforeseen accidents. It should be far from the commercial center's factories, traffic noise, and ambling chess. It must be accessible to all. The one-story building is preferred, fireproof with wide, convenient corridors and doors that open outwards. It must have enough classrooms to accommodate its learners both for the morning and afternoon sessions.

Espedido (2016), added stressed that experiences on the basic principles movements like jumping, hopping, leaping, rhythmical, skipping, stretching, and bending are provided to develop their motor skills and music coordination. The outdoor play area must afford children a space wide enough for them to run around and about, play freely, and explore safely. Shady trees and hedges can be both protective and beneficial for the children and flower and vegetable gardens can provide interesting and profitable experiences for them. Apparatus and equipment must be properly built, sturdy, and safe. Outdoor and indoor learning environments should be motivating and inviting to all children so that they are encouraged and helped to explore and to use all the possibilities offered for fun, adventure, challenge, and creativity as cited in NCCA (2014, p.54). Smith et al. (2013) believed in the importance of first-hand experiences and active learning. Convinced of the value of play she ensured there were ample materials available to stimulate children's imaginations. This section provides a general overview of supportive physical environments.

The physical environment, both indoors and outdoors, encourages positive growth and development for children through opportunities to explore and learn as posited by Finch (2013). Safe, clean, spacious, bright, welcoming, warm, and accessible environments for children and adults, including those with additional needs, should afford opportunities to rest and play. Babies, toddlers, and young children need fresh air and outdoor play space is essential if children are to have a balanced, healthy day. Learning is constrained and may be damaged if young children are required to sit still indoors, where adults do most of the talking and require children to follow their lead according to Bruce (2014). The environment should offer children opportunities to actively explore, make decisions and follow through with their ideas; engage in co-operative, symbolic, dramatic, or pretend play; move, 
dance, and increase control over their bodies cited by Hohmann and Weikart (2015). The socio-cultural theory is concerned with children's learning in context. Children respond to the reality they see around them and what they learn reflects that reality (Penn 2015). Environments can reflect the lives and activities of the children/families in the service to establish positive identities. In addition, environments can have resources to counteract stereotypical and discriminatory attitudes according to French (2013). The same principles apply whether organizing indoor or outdoor areas. In fact, many of the activities babies, toddlers, and young children enjoy indoors can be achieved outdoors and with greater freedom. If in group care, careful consideration of the organizing of rooms for different age groups is necessary. Babies and toddlers need a room or home base where they can relate for part of the day with a small group of children and adults, where they can feel secure and build relationships. Older children need more space cited by French (2013).

Montessori (cited in Smith et al. 2013), advocated that the learning environment should be carefully planned to meet children's needs by providing them with the optimum opportunities to work independently, to make choices, decisions and solve problems, to engage in real experiences and to experience success. The High/Scope Educational Research Foundation suggested space should be inviting for children and organized into well-defined areas of interest to encourage distinctive types of play. It is also noted that the interest areas are arranged to promote visibility and easy movement between areas and are flexible to accommodate ... children's changing interests. Steiner promoted a variety of easily accessible, open-ended, natural, found, real-life, materials which can be used in creative and purposeful ways and reflect children's family lives (Curtis and O'Hagan 2013). Materials are stored so that children can find, use, and return materials they need. The most effective learning comes from simple but versatile materials and environments which extend the child's imagination and can be adapted by children to suit their learning needs and level of understanding. Dowling (2013) referred to this as an informational environment that supports children's ability to make and learn from mistakes, discover the best way of doing things, and learn how to make decisions. The power of the environment is portrayed through Malaguzzi's (2016) words: “... we consider the (physical) environment to be an essential constituent element of any theoretical or political research in education ... we place enormous value on the role of the environment as a motivating and animating force in creating spaces for relations, options, and emotional and cognitive situations that produce a sense of well-being and security."

In terms of monitoring and evaluation, Elkind (2014) one such evaluator of a quality pre-school is the characteristics of the programs. The effectiveness of the program varies with the teacher's training. Child - to - teacher ratio, availability of materials, and adequacy of the physical facilities. With all of these, it is not possible to make any generalization about the benefits of early education programs. This is a very important point that must be acknowledged or acted upon. Thus, a setting in which children can fully exercise all the vicissitudes of their early childhood years is the very best preparation for a successful transition to later stages of life. Brown (2016) discussed in her book the basic principles and objectives of the education of children of pre-school age as well as activities relating to time, art, play, health and safely provided for pre-school children. She said, to ensure quality education, the quality school must base its programs according to its principles and philosophies.

Carini (2015) commented in her article "Building Curriculum for Young Children from an Experimental Base," say that "if early childhood educators are going to devote themselves to bringing ever more out of the child," and to gaining the Childs' first-hand involvement, then we have set ourselves the tasks of understanding the child's interest and thus achieved strengthened the "inner correctness of the experience." Stinson (2014) stresses the increasing recognition that education for young children includes not only the development of everyday living placement. There is a need to give rich play activities to children to develop their creativity by providing them educational materials.

In the Philippine Educational System, regulations for Kindergarten education such as the Republic Act no. 10157 of 2012 otherwise known as the Kindergarten Education Act and the "Enhanced Basic Education Act of 2013" (Republic Act No. 10533), This act was created and implemented to ensure a mandatory and compulsory Kindergarten Education that effectively promotes physical, social, cognitive, and emotional skills stimulation and values formation offered to all five (5)-year old Filipino children to sufficiently prepare them for Grade One.

Pursuant to this provision, the Department of Education or DepEd who offers a kindergarten education program for pupils in the public and private sectors sets a guideline in the implementation of the Basic Education Program. The said department issued a DepEd Order no.47, series of 2016 or 
otherwise known as Omnibus Policy on Kindergarten Education which sets the basic standards for an efficient and effective Kindergarten Education Program for compliance and delivery for both public and private schools nationwide and serves as a basis for accreditation and/or recognition of school administrators and of those intending to put up early learning centers. Furthermore, the said DepEd order provides a comprehensive kindergarten education policy covering the following different components of implementing Kindergarten Education Programs as to; curriculum, an instruction such as teaching methodologies and strategies, assessment, learning resources and instructional materials, learning space environment, monitoring and evaluation for the standard delivery of kindergarten services.

The primary researcher is an elementary teacher with a passion for early childhood education through his direct observation and assistance due to a huge number of pupils of his fellow teachers handling kindergarten education program. Hence, this motivated him to undertake this study particularly the implementation of an omnibus policy for kindergarten education in cluster 2 public elementary schools in the City Schools Division of Dasmariñas. The results of this study would serve as a basis for proposed enhancement training for kindergarten teachers and administrators particularly on the implementation of the omnibus policy itself which aims to strengthen and improve the delivery of quality kindergarten education.

\section{METHODOLOGY}

This study utilized a descriptive - normative survey method of investigation to secure adequate and reliable data. The researchers used this design to gather necessary data, assess and determine the implementation of omnibus policy on kindergarten education in cluster 2, public elementary schools under the City Schools Division of Dasmariñas. The respondents in this study are the Kindergarten teachers which were specifically confined at Cluster 2 which has four (4) schools as follows; Humayao Elementary School, Langkaan Elementary School, Sabang Elementary School, and Ramona S. Tirona Memorial School. The said schools are under the jurisdiction of the City Schools Division of Dasmariñas, which is strategically located at Dasca, Compound, Burol II, City of Dasmariñas, Cavite, Region IV-A Calabarzon.

In securing a permit to conduct the study, the permit to conduct the study was requested and filed to the office of the Schools Division Superintendent of the City School Division Office of Dasmariñas. Before the actual data gathering, the researchers have conducted a pilot study to earning unit students in Early Childhood Education enrolled at Northeastern College, Santiago City during the second semester of the school year 2018-2019. They were chosen purposively from the total number of the population but were not included in the actual data gathering. The data that was gathered from the pilot study were submitted to the statistician for the test of its reliability coefficient. The internal consistency coefficient using Cronbach alpha must be greater than 0.05 level of significance to be reliable and accepted. When the questionnaire is determined to be reliable, the researchers proceeded with the actual data gathering. In administering the questionnaire, the researchers personally distributed the questionnaire to the selected identified respondents to ensure a hundred percent retrieval and to attend possible queries that may arise. The researchers used purposive sampling in selecting the possible respondents. After the retrieval, the data were tallied, tabulated, and computed to facilitate the analysis and interpretation.

In the preparation of the questionnaire, the researchers considered the validity, briefness, interest, and appeal of the questions that will be asked; the depth of the responses, and convenience on the part of the respondents. To ensure a higher percentage of returns, the data gathering instrument was prepared in such a way that the items could be answered by a checkmark. The questionnaire checklist was based on DepEd Order no. 47, series of 2016. It contains the following: Part I - Respondents' profile to some selected variables as stated in the statement of the problem, Part II is the level of implementation of omnibus policy on kindergarten education program as perceived by the respondents. The omnibus policy to be assessed is instruction, assessment, learning resources and materials, learning space and environment, monitoring and evaluation for the standard delivery of kindergarten services, and problems encountered in the implementation of the program. Specific items in the questionnaire under instruction and monitoring and evaluation were formulated based on the Omnibus Policy on 
Kindergarten Education, and with the guidance and recommendations of a Kindergarten Specialist and Kindergarten School Administrator.

The statistical tools which are used in the analysis of data are as follows; Frequency percentage in order to determine the profile of the respondents, weighted mean was utilized in treating the primary variables of the study on the implementation on the omnibus policy of kindergarten education, and problems encountered by the respondents; Chi-square test was used to determine the significant relationship between implementation on omnibus policy kindergarten education to the profile of the respondents, and Analysis of variance (ANOVA) was used to test the significant difference between implementation on omnibus policy kindergarten education to the profile of the respondents.

For the purpose of data analysis and qualitative interpretation, Likert-typed scale was used with corresponding values in Table 1, Table 2 and Table 3.

Table 1. Criteria to identify the mean of instruction, assessment, monitoring and evaluation.

\begin{tabular}{|c|c|c|}
\hline Scale & Qualitative Description & Range \\
\hline 5 & Always Observed & $4.20-5.00$ \\
\hline 4 & Often Observed & $3.40-4.19$ \\
\hline 3 & Sometimes Observed & $2.60-3.39$ \\
\hline 2 & Seldom Observed & $1.80-2.59$ \\
\hline 1 & Never Observed & $1.00-1.79$ \\
\hline
\end{tabular}

Table 2. Likert scale to determine the learning resources, instructional materials, learning space and environment

\begin{tabular}{|c|c|c|}
\hline Scale & Qualitative Description & Range \\
\hline 5 & Highly Adequate & $4.20-5.00$ \\
\hline 4 & Very Adequate & $3.40-4.19$ \\
\hline 3 & Adequate & $2.60-3.39$ \\
\hline 2 & Fairly Adequate & $1.80-2.59$ \\
\hline 1 & Inadequate & $1.00-1.79$ \\
\hline
\end{tabular}

Table 3. Likert scale to determine the problems encountered

\begin{tabular}{|c|c|c|}
\hline Scale & Qualitative Description & Range \\
\hline 5 & Very great extent & $4.20-5.00$ \\
\hline 4 & Great extent & $3.40-4.19$ \\
\hline 3 & Moderate extent & $2.60-3.39$ \\
\hline 2 & Little extent & $1.80-2.59$ \\
\hline 1 & Very little extent & $1.00-1.79$ \\
\hline
\end{tabular}

\section{RESULTS AND DISCUSSION}

\section{Profile of the Respondents}

It is evident in Table 4 that nearly half of the total respondents (11 or 64.71 percent) are below 29 years old. Whereas, 3 or 17.65 percent are within the age of $35-39$ years old and only 1 or 5.88 percent is between $45-49$ years old, $40-44$ years old, and 30 -34 years of age. This implies that the majority of the teacher respondents are beginning in their endeavor as Early Childhood Education teachers. 
Table 4. Respondents Profile as to Age

\begin{tabular}{|c|c|c|}
\hline Age & Frequency & Percentage \\
\hline $45-49$ & 1 & 5.88 \\
\hline $40-44$ & 1 & 5.88 \\
\hline $35-39$ & 3 & 17.65 \\
\hline $30-34$ & 1 & 5.88 \\
\hline $29-$ below & 11 & 64.71 \\
\hline Total & 17 & 100 \\
\hline
\end{tabular}

Table 5. Respondents Profile as to Sex

\begin{tabular}{|c|c|c|}
\hline Sex & Frequency & Percentage \\
\hline Male & 0 & 0 \\
\hline Female & 17 & 100.00 \\
\hline Total & 17 & 100 \\
\hline
\end{tabular}

As shown in Table 5, all of the respondents are female. This may imply that the teaching profession is mostly dominated by females specifically in handing early childhood learners. This further implies that women are inherently nurturer with a passion for teaching and care for the young.

Table 6. Respondents Profile as to Civil Status

\begin{tabular}{|c|c|c|}
\hline Civil Status & Frequency & Percentage \\
\hline Single & 9 & 52.94 \\
\hline Married & 7 & 41.18 \\
\hline Separated & 1 & 5.88 \\
\hline Total & 17 & 100 \\
\hline
\end{tabular}

Table 6 reveals that the majority of the respondents are single with a frequency of 9 or 52.94 percent; 7 or 41.18 are married and 1 or 5.88 are separated. This data supports Table 4 which shows that majority are in the early '20s of their age.

Table 7. Respondents Profile as to Educational Attainment and Specialization

\begin{tabular}{|c|c|c|}
\hline Educational Attainment & Frequency & Percentage \\
\hline Post Graduate Studies & 3 & 17.65 \\
\hline Graduate Studies & 6 & 35.29 \\
\hline Bachelor's Degree & 8 & 47.06 \\
\hline Total & 17 & 100 \\
\hline Specialization: & 17 & 100 \\
\hline
\end{tabular}

It is evident from Table 7 that 8 or 47.06 percent of the respondents are bachelor's degree holders; 6 or 35.29 percent have obtained their graduate studies and 3 or 17.65 percent have conferred with their post-graduate studies. Furthermore, based on the survey, the researcher counter checked through an unstructured interview that all of the respondents are graduate of Bachelor of Elementary Education major in Early Childhood Education, most of their graduate studies are also vertical to their undergraduate course. However when it comes to their post-graduate studies most of them are Doctor of Philosophy in Education, major in Educational Management. 
In addition, the researcher also validated the above data through informal interviews revealed that a geographical distance of a graduate school who offers vertical specialization such as Master of Arts in Early Childhood Education or any other related courses, some reasons noted are maybe related to financial and time constrain.

This further implies that the majority of the ECE teachers handling kindergarten class have obtained their master's degree which academically qualifies them to teach and handle the said curriculum program, and complied with the requirements stated and mandated in the DepEd Order 12, s. 2012 and Section 7.1.2. of the Deped Order number 7, series of 2015 which states the additional requirements for kindergarten teachers and reinforced by DepEd Order No. 9, series of 2016 by the former Department of Education Secretary, Br. Armin A Luistro, FSC.

Table 8. Respondents Profile as to Position

\begin{tabular}{|c|c|c|}
\hline Position & Frequency & Percentage \\
\hline Teacher I & 15 & 88.24 \\
\hline Teacher II & 2 & 11.76 \\
\hline Total & 17 & 100 \\
\hline
\end{tabular}

Data shows that almost all of the teacher respondents are Teacher I with a frequency of 15 or 88.24 percent and 2 or 11.76 are Teacher II. It is perceived that higher positions in teaching are based on the available plantilla offered by the Schools City Division of Dasmariñas. Further, Items for Kindergarten teacher in the public school was offered only in 2012 when $\mathrm{K}$ to 12 Curriculum was implemented.

Table 9. Respondents Profile as to Nature of Appointment

\begin{tabular}{|c|c|c|}
\hline Nature of Appointment & Frequency & Percentage \\
\hline Regular & 17 & 100 \\
\hline Total & 17 & 100 \\
\hline
\end{tabular}

As seen in Table 9, it is clear to note that all of the respondents have regular employment status in the government.

Table 10. Respondents Profile as to Years of Teaching in Early Childhood Education

\begin{tabular}{|c|c|c|}
\hline Years of Teaching in ECE & Frequency & Percentage \\
\hline $16-$ above & 1 & 5.88 \\
\hline $11-15$ years & 3 & 17.65 \\
\hline $6-10$ years & 1 & 5.88 \\
\hline $1-5$ years & 11 & 64.71 \\
\hline Below 1 year & 1 & 5.88 \\
\hline Total & 17 & 100 \\
\hline
\end{tabular}

Data reveals that majority of the teacher had have $1-5$ years of teaching early childhood education with a frequency of 11 or 64.71 percent; 3 or 17.65 have $11-15$ years in teaching and 1 or 5.88 percent had have16 years and above, $6-10$ years and below 1 year in teaching. This implies that the majority of the teachers handling ECE have permanent employment status. Furthermore, the respondents complied with the specific criteria specifically indicated in Section 5.3.2 of DepEd Order 12, s. 2012.

Table 11. Respondents Profile as to Eligibility

\begin{tabular}{|c|c|c|}
\hline Eligibility & Frequency & Percentage \\
\hline LET & 17 & 100 \\
\hline Total & 17 & 100 \\
\hline
\end{tabular}


It could be gleaned from the above data that all of the respondents have passed the Licensure Examination for Teachers qualified them to become a civil service eligible which is a requirement in the hiring of teachers in the public school or Department of Education. This further implies that the teachers complied in section 5.3.3 of the DepEd Order 12, series, 2012.

Table 12. Respondents Profile as to Trainings Attended

\begin{tabular}{|c|c|c|}
\hline Level & Frequency of Mention & Rank \\
\hline National & 5 & 3 \\
\hline Regional & 10 & 2 \\
\hline Division & 27 & 1 \\
\hline School & 0 & \\
\hline Total & 42 & \\
\hline
\end{tabular}

The table shows that the majority of the respondents (frequency of 25) have attended division-level training, 10 are regional and 5 attended a national level. This implies that most of their training is division level due to insufficient funds as validated through an informal interview by the writer. It was noted that school-based seminars and training were never conducted since only a few participants or never the less only one (1) or two (2) teachers per elementary school handling the Kindergarten program.

\section{Implementation on Omnibus Policy on Kindergarten Education}

\section{The data in}

Table 13(a) shows that particulars under teaching methodologies and strategies were all posted "Always Observed" by the respondents. It is significant that all items under Medium of Instruction, Thematic Approach, Developmentally Appropriate Practices.

Table 13(a). Instruction: Teaching Methodologies and Strategies

\begin{tabular}{|c|c|c|}
\hline Instruction: Teaching Methodologies and Strategies & \multirow[t]{2}{*}{ Mean } & \multirow[t]{2}{*}{ Description } \\
\hline 1. Medium of Instruction & & \\
\hline 1.1. Mother Tongue as a primary mode of teaching and learning & 4.82 & $\begin{array}{l}\text { Always } \\
\text { Observed }\end{array}$ \\
\hline 1.2. Follows a class program knows as the Blocks of time & 4.53 & $\begin{array}{l}\text { Always } \\
\text { Observed }\end{array}$ \\
\hline $\begin{array}{l}\text { 1.3. Provide balance program of daily activities such as quiet and active, } \\
\text { structured, and unstructured. }\end{array}$ & 4.47 & $\begin{array}{c}\text { Always } \\
\text { Observed }\end{array}$ \\
\hline \multicolumn{3}{|l|}{ 2. Thematic Approach } \\
\hline 2.1. Learning activities are organized into thematic units or teaching themes. & 4.35 & $\begin{array}{l}\text { Always } \\
\text { Observed }\end{array}$ \\
\hline $\begin{array}{l}\text { 2.2. Thematic units integrate concepts and skills from the seven } \\
\text { developmental domains-Myself, My School, My Community, and other } \\
\text { Others Around Me. }\end{array}$ & 4.65 & $\begin{array}{l}\text { Always } \\
\text { Observed }\end{array}$ \\
\hline $\begin{array}{l}\text { 2.3. Teachers plan for one topic per week or month depending on the } \\
\text { broadness of the theme. }\end{array}$ & 4.53 & $\begin{array}{l}\text { Always } \\
\text { Observed }\end{array}$ \\
\hline $\begin{array}{l}\text { 2.4. Music, creative arts, dramatics, and creative movements are used to } \\
\text { enrich the core lesson for the day. }\end{array}$ & 4.65 & $\begin{array}{c}\text { Always } \\
\text { Observed }\end{array}$ \\
\hline \multicolumn{3}{|l|}{ 3. Developmentally Appropriate Practices } \\
\hline 3.1. Provide learning activities for the holistic development of each child. & 4.35 & $\begin{array}{c}\text { Always } \\
\text { Observed }\end{array}$ \\
\hline $\begin{array}{l}\text { 3.2. Observe individual differences of each child in terms of personality, } \\
\text { needs, and interests. }\end{array}$ & 4.47 & $\begin{array}{l}\text { Always } \\
\text { Observed }\end{array}$ \\
\hline 3.3. Respect the religious, and socio-cultural background of each child. & 4.35 & $\begin{array}{l}\text { Always } \\
\text { Observed }\end{array}$ \\
\hline
\end{tabular}


3.4. Teach each child based on his/her mental abilities and capabilities, age level, and readiness.

\begin{tabular}{|c|c|}
\hline 4.41 & $\begin{array}{c}\text { Always } \\
\text { Observed }\end{array}$ \\
$\mathbf{4 . 5 1}$ & $\begin{array}{c}\text { Always } \\
\text { Observed }\end{array}$ \\
\hline
\end{tabular}

Table 13(b). Instruction: Teaching Methodologies and Strategies

\begin{tabular}{|c|c|c|}
\hline Instruction: Teaching Methodologies and Strategies & Mean & Description \\
\hline 4. Constructivist Approach & & \\
\hline 4.1. Discovery Learning & & \\
\hline 4.1.1. Free guided play in the different learning areas or corners & & \\
\hline $\begin{array}{l}\text { a. Language Arts corner (listening, oral, reading, writing, viewing } \\
\text { activities) }\end{array}$ & 4.24 & $\begin{array}{l}\text { Always } \\
\text { Observed }\end{array}$ \\
\hline b. Sensory-Perceptual and Numeracy corner & 4.29 & $\begin{array}{c}\text { Always } \\
\text { Observed }\end{array}$ \\
\hline c. Motor and Creative Development Corner & 4.35 & $\begin{array}{l}\text { Always } \\
\text { Observed }\end{array}$ \\
\hline d. Dramatic Play/ Housekeeping Area & 4.12 & $\begin{array}{c}\text { Often } \\
\text { Observed }\end{array}$ \\
\hline 4.1.2. $\quad$ Simple experiments & 3.94 & $\begin{array}{c}\text { Often } \\
\text { Observed }\end{array}$ \\
\hline 4.2. Inquiry-based Approach & & \\
\hline 4.2.1. Observation in the natural environment related to the lesson & 4.35 & $\begin{array}{l}\text { Always } \\
\text { Observed }\end{array}$ \\
\hline 4.2.2. Educational Field trips with parents/guardians & 3.71 & $\begin{array}{c}\text { Often } \\
\text { Observed }\end{array}$ \\
\hline 4.3. $\quad$ Cooperative Approach & & \\
\hline 4.3.1. Cooperative learning activities are used from time to time. & 4.65 & $\begin{array}{l}\text { Always } \\
\text { Observed }\end{array}$ \\
\hline 4.3.2. Big group and small group learning activities are done daily. & 4.47 & $\begin{array}{l}\text { Always } \\
\text { Observed }\end{array}$ \\
\hline $\begin{array}{l}\text { 4.3.3. Socialization activities among the pupils are present in the entire } \\
\text { duration of the daily class program. }\end{array}$ & 4.59 & $\begin{array}{l}\text { Always } \\
\text { Observed }\end{array}$ \\
\hline 4.4. Individualized Instruction & & \\
\hline $\begin{array}{l}\text { 4.4.1. One-on-one teaching in reading, writing, and math (3Rs) at least } \\
\text { once or twice a week to meet the individual mental abilities and } \\
\text { basic academic needs of each child. }\end{array}$ & 4.18 & $\begin{array}{c}\text { Often } \\
\text { Observed }\end{array}$ \\
\hline 4.5. $\quad$ Differentiated Learning & & \\
\hline $\begin{array}{l}\text { 4.5.1. Uses differentiated learning activities based on the multiple } \\
\text { intelligences of pupils. }\end{array}$ & 4.41 & $\begin{array}{l}\text { Always } \\
\text { Observed }\end{array}$ \\
\hline 4.5.2. Observes the different learning styles of pupils & 4.35 & $\begin{array}{l}\text { Always } \\
\text { Observed }\end{array}$ \\
\hline 4.6. Technology-based Learning & & \\
\hline a. Uses modern technology such as ICT in teaching & 4.18 & $\begin{array}{c}\text { Often } \\
\text { Observed }\end{array}$ \\
\hline Reflective and Play-based Activities & & \\
\hline 4.7.1. Unstructured or free play activities & & \\
\hline a. Indoor play in the different learning corners & 4.35 & $\begin{array}{l}\text { Always } \\
\text { Observed }\end{array}$ \\
\hline b. Outdoor play for physical development & 4.00 & $\begin{array}{c}\text { Often } \\
\text { Observed }\end{array}$ \\
\hline 4.7.2. Teacher-directed Play Activities & & \\
\hline a. Games related to the lesson & 4.35 & $\begin{array}{l}\text { Always } \\
\text { Observed }\end{array}$ \\
\hline b. Play-based teaching strategies related to the lesson & 4.41 & $\begin{array}{c}\text { Always } \\
\text { Observed }\end{array}$ \\
\hline
\end{tabular}




\begin{tabular}{|c|c|c|}
\hline Average Mean & $\mathbf{4 . 2 7}$ & $\begin{array}{c}\text { Always } \\
\text { Observed }\end{array}$ \\
\hline
\end{tabular}

Table 13(b) shows that particulars under teaching methodologies and strategies were mostly posted "Always Observed" and some were felt "Often Observed" by the respondents. It is significant that all items under Cooperative Approach and Differentiated Learning were posted "Always Observed" of varied means. On the contrary, teachers posted "Often Observed" on Dramatic Play/ Housekeeping Area, Simple experiments, Individualized instruction in 3Rs, Uses of modern technology, and Outdoor Play for Physical Development. It is note taking that Educational trips, Simple experiments, and Outdoor play equipment were the least felt often observed as expected from public schools due to financial constraints.

The data implies that there is a need to improve the least observed items on Discovery learning, Inquiry-based approach, Individualized instruction, Technology-based Learning, and Play-Based activities to make learning more effective and efficient to young learners.

The result affirms the idea of Ravalo (2015) who emphasized on the importance of contents and methodologies in teaching different subject areas, the primordial goals of which is quality education. According to him, a teacher should be fully aware that he can teach effectively and efficiently if he possesses the necessary knowledge of subject-matter, the methodology and most of all know learners when he is working with. The extent of his knowledge about them will help him in determining their potential, need and interest and how they can be enhance directed up to the optimum. His knowledge about his pupils or students will help serve as the foundation of his teaching - thus creating a good school.

Table 14. Perceived Implementation of Assessment by the Respondents

\begin{tabular}{|c|c|c|}
\hline Assessment & Mean & Description \\
\hline \multicolumn{3}{|l|}{ 1. Formative Assessment } \\
\hline $\begin{array}{l}\text { 1.1. Observation: Observing children during whole-group activities, } \\
\text { individualized instruction, free guided play, and the entire duration of the } \\
\text { session each day. }\end{array}$ & 4.53 & $\begin{array}{l}\text { Always } \\
\text { Observed }\end{array}$ \\
\hline 1.2. Collection of individual pupil's work & 4.82 & $\begin{array}{c}\text { Always } \\
\text { Observed }\end{array}$ \\
\hline 1.3. Anecdotal record per child & 4.12 & $\begin{array}{c}\text { Always } \\
\text { Observed }\end{array}$ \\
\hline 1.4. A daily log of progress record of each child & 4.00 & $\begin{array}{c}\text { Often } \\
\text { Observed }\end{array}$ \\
\hline \multicolumn{3}{|l|}{ 2. Summative Assessment } \\
\hline 2.1. Oral test & 4.29 & $\begin{array}{l}\text { Always } \\
\text { Observed }\end{array}$ \\
\hline 2.2. Written test & 4.29 & $\begin{array}{c}\text { Always } \\
\text { Observed }\end{array}$ \\
\hline 2.3. Portfolio & 4.41 & $\begin{array}{c}\text { Always } \\
\text { Observed }\end{array}$ \\
\hline \multicolumn{3}{|l|}{ 3. $\quad$ Evaluation Form } \\
\hline 3.1. Individual Checklist of Progress Report & 4.76 & $\begin{array}{c}\text { Always } \\
\text { Observed }\end{array}$ \\
\hline 3.2. Progress Report Card & 4.59 & $\begin{array}{l}\text { Always } \\
\text { Observed }\end{array}$ \\
\hline 4. Individual Parent-Teacher Conference every quarter & 4.35 & $\begin{array}{c}\text { Always } \\
\text { Observed }\end{array}$ \\
\hline Average Mean & 4.42 & $\begin{array}{c}\text { Always } \\
\text { Observed }\end{array}$ \\
\hline
\end{tabular}

The overall mean of respondent's perception in terms of assessment is 4.42 or always observed. The findings in formative assessment indicate that teachers always observed their children during wholegroup activities, Individualized instruction, Free guided play, and the entire duration of the session each 
day and Collection of individual pupil's work. Furthermore, in summative assessments such as oral tests; written tests and portfolios, evaluation forms such as an individual checklist of progress report and progress report card are also used by teachers and always observed. Similarly, Individual ParentTeacher Conference every quarter is also noted as always observed. However, Anecdotal record and Daily $\log$ of pupil's progress were posted with the least means of 4.12 and 4.00 described as "Often Observed".

The data imply that assessment is always and well observed by the respondents but there is a need to enhance the use of anecdotal records and daily progress report log of each child because these are the primary bases of the teacher in the Kindergarten Progress Report Checklist.

Table 15(a). Learning Resources and Instructional Materials

\begin{tabular}{|c|c|c|}
\hline Learning Resources and Instructional Materials & Mean & Description \\
\hline 1. Presence of manipulative toys & & \\
\hline a. Table blocks & 3.88 & Very Adequate \\
\hline b. Lacing beads & 3.35 & Adequate \\
\hline c. Tangrams & 3.24 & Adequate \\
\hline d. Counting frame & 3.12 & Adequate \\
\hline e. Picture dominoes & 3.53 & Very Adequate \\
\hline f. Jigsaw puzzles & 3.65 & Very Adequate \\
\hline g. Counters & 3.47 & Very Adequate \\
\hline 2. Activity cards/board games & & \\
\hline a. Cover all and call out games & 3.53 & Very Adequate \\
\hline b. Uppercase letters & 4.00 & Very Adequate \\
\hline c. Lowercase letters & 4.00 & Very Adequate \\
\hline d. Colors & 4.00 & Very Adequate \\
\hline e. Numbers & 4.06 & Very Adequate \\
\hline f. Shapes & 3.71 & Very Adequate \\
\hline g. Connecting games & 3.82 & Very Adequate \\
\hline h. Picking up games & 3.71 & Very Adequate \\
\hline Average & $\mathbf{3 . 6 7}$ & Very Adequate \\
\hline
\end{tabular}

Data shows that very adequate is noted in the presence of manipulative toys such as table blocks; picture dominoes; jigsaw puzzles and counters, activity cards/board games such as cover all and call out games; uppercase letters; lowercase letters; colors; numbers; shapes; connecting games; and picking up games. However, adequate is noted in the presence of manipulative toys such as; lacing beads; tangrams, and counting frames.

Table 15(b). Learning Resources and Instructional Materials

\begin{tabular}{|l|c|c|}
\hline $\begin{array}{l}\text { 3. Learner's Material (Readiness Activity Sheets) and Teacher-Made } \\
\text { activity sheets }\end{array}$ & Mean & Description \\
\hline 3.1. Books & & \\
\hline a. Read-aloud books or big books & 3.71 & Very Adequate \\
\hline b. Small books & 3.65 & Very Adequate \\
\hline c. Picture storybooks & 3.76 & Very Adequate \\
\hline d. Wordless picture books & 3.35 & Adequate \\
\hline e. Concept books & 2.82 & Adequate \\
\hline f. Board books & 2.88 & Adequate \\
\hline 3.2. Open-ended sensory materials & & \\
\hline a. Sand and water & 2.47 & Adequate \\
\hline b. Clay or home-made play dough & 3.06 & Adequate \\
\hline
\end{tabular}




\begin{tabular}{|l|c|c|}
\hline 3.3. Multimedia and computer-aided materials & & \\
\hline a. Songs & 4.29 & $\begin{array}{c}\text { Highly } \\
\text { Adequate }\end{array}$ \\
\hline b. Rhymes & 4.35 & $\begin{array}{c}\text { Highly } \\
\text { Adequate }\end{array}$ \\
\hline c. Movies in CD/DVD & 4.35 & $\begin{array}{c}\text { Highly } \\
\text { Adequate }\end{array}$ \\
\hline d. Interactive educational games & 4.06 & Very Adequate \\
\hline $\begin{array}{l}\text { Indigenous instructional materials or locally produced or parent-made } \\
\text { toys and play equipment Average Mean }\end{array}$ & 4.18 & Very Adequate \\
\hline \multicolumn{1}{|c|}{ A.61 } & $\begin{array}{c}\text { Very } \\
\text { Adequate }\end{array}$ \\
\hline
\end{tabular}

The results of the descriptive study showed that there is a highly adequate presence of the items that are more than enough needed in school such as songs; rhymes and movies in CD/DVD. However, very adequate is noted in the learner's material (Readiness Activity Sheets) and Teacher-made activity sheets, books, such as read-aloud books or big books; small books; and picture storybooks and interactive educational games and Indigenous instructional materials or locally produced or parent-made toys and play equipment. Whereas, there is adequate or but just enough of the requirements needed in the school are noted such as books, wordless picture books, concept books, board books, open-ended sensory materials such as sand and water, and clay home-made playdough. The data revealed that wordless picture books, concepts books, and board books need to be provided. Much more so with sand and water play, and clay dough for sensory-motor development of young learners.

Table 16(a). Learning Space and Environment

\begin{tabular}{|c|c|c|}
\hline Learning Space and Environment & Mean & Description \\
\hline \multicolumn{3}{|l|}{ 1. Classroom Size } \\
\hline a. The standard classroom size is $7 \mathrm{~m} \times 9 \mathrm{~m}$ & 3.53 & Very Adequate \\
\hline $\begin{array}{l}\text { b. The school's has allocated a classroom exclusively for Kindergarten } \\
\text { with 1:1 teacher-classroom ratio }\end{array}$ & 3.53 & Very Adequate \\
\hline $\begin{array}{l}\text { c. Kindergarten classroom is located on the ground floor and must be } \\
\text { next to the nearest and/or exit access points }\end{array}$ & 3.71 & Very Adequate \\
\hline \multicolumn{3}{|l|}{ 2. Furniture and Equipment } \\
\hline a. 5 tables and 30 chairs & 3.76 & Very Adequate \\
\hline b. 1 set of Teacher's table and chair & 3.82 & Very Adequate \\
\hline c. 1 Teacher's cabinet & 4.12 & Very Adequate \\
\hline d. 1 open shelf for the manipulative toys & 4.29 & Highly Adequate \\
\hline e. 1 open shelf for storybooks & 3.76 & Very Adequate \\
\hline f. open shelf for the Learner's Materials & 3.59 & Very Adequate \\
\hline g. 1 unit Kindergarten cubby for the learner's personal belongings & 3.53 & Very Adequate \\
\hline h. 1 unit ceiling fan & 4.06 & Very Adequate \\
\hline i. 2 units wall fan & 4.24 & Highly Adequate \\
\hline $\begin{array}{l}\text { 2.1. The mounting of a clean multifunction blackboard or whiteboard is } \\
\text { at the eye level and reach of the children }\end{array}$ & 4.18 & Very Adequate \\
\hline 2.2. Water, sanitation, and hygiene facilities & & \\
\hline a. Toilet & 4.35 & Highly Adequate \\
\hline b. Bathroom & 4.18 & Very Adequate \\
\hline $\begin{array}{l}\text { c. Handwashing facilities must be suitable for the height of } \\
\text { Kindergarten children }\end{array}$ & 3.82 & Very Adequate \\
\hline $\begin{array}{l}\text { 2.3. Proper and adequate lighting (natural and electric lighting), and } \\
\text { ventilation for a } 7 \mathrm{~m} \times 9 \mathrm{~m} \text { classroom, should have at least two } 40 \text { - } \\
\text { watt fluorescent lamps, and one wide window (2010 Educational } \\
\text { Facilities Manual) }\end{array}$ & 4.18 & Very Adequate \\
\hline
\end{tabular}




\begin{tabular}{|r|c|c|}
\hline 2.4. & $\begin{array}{l}\text { Emergency equipment and tools should be present inside the } \\
\text { classroom }\end{array}$ & \\
\hline a. Fire extinguisher & 2.88 & Adequate \\
\hline b. Flashlight & 3.12 & Adequate \\
\hline c. Whistle & 3.29 & Adequate \\
\hline d. Medical Kit & 4.06 & Very Adequate \\
\hline Average & $\mathbf{3 . 8 1}$ & Very Adequate \\
\hline
\end{tabular}

The table shows that in terms of learning space and environment teacher respondents perceived that there are highly adequate or more than enough of the requirements needed in the school such as furniture and equipment like 1 open shelf for the manipulative toys and 2 units wall fan, water, sanitation, and hygiene facilities such as the toilet.

Teachers' perceived that their school has very adequate classroom size or complied with the standards $(7 \mathrm{~m} \times 9 \mathrm{~m})$; their school has allotted a classroom exclusively for Kindergarten with 1:1 teacher-classroom ratio and their classroom is located on the ground floor next to the nearest and/or exit access points. Furniture and equipment such as 5 tables and 30 chairs; 1 set of Teacher's table and chair; 1 Teacher's cabinet; 1 open shelf for the manipulative toys; 1 open shelf for storybooks; 1 open shelf for the Learner's Materials; 1 unit Kindergarten cubby for the learner's personal belongings; and 1 unit ceiling fan are also very adequate. The mounting of a clean multifunction blackboard or whiteboard are at the eye level and reach of the children, water, sanitation, hygiene facilities such bathroom; and washing facilities are suitable to the height of Kindergarten children; proper and adequate lighting (natural and electric lighting), and ventilation for a $7 \mathrm{~m} \mathrm{x} 9 \mathrm{~m}$ classroom, they have at least two 40 -watt fluorescent lamps, and one wide window, and medical kit. Emergency equipment and tools are also present inside the classroom such as fire extinguisher, flashlight, and whistle are also noted as adequate.

Table 16(b). Learning Space and Environment

\begin{tabular}{|c|c|c|}
\hline Learning Space and Environment & Mean & Description \\
\hline \multicolumn{3}{|l|}{ 3. Activity Corners (2010 Educational Facilities Manual) } \\
\hline 3.1. Personal Care and Grooming & & \\
\hline a. Mirror & 3.00 & Adequate \\
\hline b. Comb & 3.76 & Adequate \\
\hline c. Towel & 4.29 & Highly Adequate \\
\hline d. Toothbrush & 3.00 & Adequate \\
\hline e. Soap & 3.35 & Adequate \\
\hline f. Toiletries & 3.24 & Adequate \\
\hline g. Nail cutter & 3.29 & Adequate \\
\hline h. Tissue paper & 4.29 & Highly Adequate \\
\hline 3.2. Language Arts Corner & & \\
\hline a. Picture storybooks & 3.65 & Very Adequate \\
\hline b. Picture concept books & 4.18 & Very Adequate \\
\hline c. Wordless books & 3.65 & Very Adequate \\
\hline d. Science/nature books & 4.41 & Highly Adequate \\
\hline e. Filipiniana & 3.35 & Very Adequate \\
\hline f. Student-or-teacher-made books & 3.94 & Very Adequate \\
\hline 3.3. Sensory-Perceptual and Numeracy Skills Corner & & \\
\hline a. Magnifying glass & 3.82 & Very Adequate \\
\hline b. Counters & 3.94 & Very Adequate \\
\hline c. Beads & 4.12 & Very Adequate \\
\hline d. Numbers cards & 4.35 & Highly Adequate \\
\hline e. Nature tables & 4.24 & Highly Adequate \\
\hline 3.4. Motor and Creative Development Corner & & \\
\hline
\end{tabular}




\begin{tabular}{|r|c|c|}
\hline a. Tambourine & 2.53 & Fairly Adequate \\
\hline b. Castanets & 2.71 & Adequate \\
\hline c. Xylophone & 3.76 & Very Adequate \\
\hline d. Woodblock & 3.24 & Adequate \\
\hline 3.5. Work Area/ Activity Area & & \\
\hline a. Tables & 4.59 & Highly Adequate \\
\hline b. Chairs & 4.53 & Highly Adequate \\
\hline c. Art and school supplies & 4.35 & Highly Adequate \\
\hline 3.6. Dramatic Play/ Free Play Area & & \\
\hline a. Household play items & 3.18 & Adequate \\
\hline b. Costumes or dress me up items & 3.65 & Very Adequate \\
\hline 4. Play Area with a minimum lot area of 360 square meters. & & \\
\hline a. Balance beam & 1.53 & Inadequate \\
\hline b. Swing & 1.59 & Inadequate \\
\hline c. Seesaw & 1.88 & Inadequate \\
\hline d. Monkey bars & 1.76 & Inadequate \\
\hline e. Sand and water play equipment & 1.59 & Inadequate \\
\hline f. Simple obstacles & 1.71 & Inadequate \\
\hline g. Slides & 1.59 & Inadequate \\
\hline & $\mathbf{3 . 5 4}$ & Very Adequate \\
\hline
\end{tabular}

Language arts corner such as Picture storybooks, picture concept books, wordless books, Filipiniana, and student or teacher-made books; sensory-perceptual and numeracy skills corner such as magnifying glass, counters, and beads. Motor and creative development corner like a xylophone; Work is/activity area (costumes or dress me up items) are noted as adequate which means that there are items but just enough in the requirements school needed. Personal care and grooming such as mirror, soap, toiletries, and nail cutter; Motor and creative development corner such as castanets and; Dramatic play/free play area such as household play items are also noted as adequate. Fairly adequate is the motor and creative development such as tambourine.

It is significantly noted that there is an inadequate play area with a minimum lot area of 360 square meters such as balance beam; swing; seesaw; monkey bars; sand and water play equipment; simple obstacles and slides. One of the basic requirements in offering a Kindergarten Education program is the presence of sufficient space for outdoor play and equipment essential for the physical, mental, social, and emotional development of young children (DepEd Order No. 47, s.2016). Hence, the data imply that the school administrators may find ways to meet the needed outdoor play equipment for the kindergartners.

Further, the data may imply that having an adequate learning space and environment may be related to the prioritization or utilization of funds and school-based management practiced by their respective school heads.

The result affirms by Bautista (2012) in his article "Quality Pre-elementary Education: Problems and Concerns". He further stated some factors that enhance teaching and learning which are the oversized class in which the quality education in the school can be better ensured with reduced class size and the size of the classroom that there must be enough chairs and tables should be provided.

Table 17. Monitoring and Evaluation for the Standard of Delivery

\begin{tabular}{|l|c|c|}
\hline Monitoring and Evaluation & Mean & Description \\
\hline $\begin{array}{l}\text { The teacher-student ratio is prescribed to be at 1:25 teacher-pupil ratio } \\
\text { and classroom pupil ratio. }\end{array}$ & 3.88 & Often Observed \\
\hline 2. $\begin{array}{l}\text { My School Head is fully equipped to supervise the Kindergarten } \\
\text { program. }\end{array}$ & \\
\hline
\end{tabular}




\begin{tabular}{|l|c|c|}
\hline 2.1. $\begin{array}{l}\text { Observed that the Quality Assurance and the School } \\
\text { Governance and Operations Divisions at the Region and } \\
\text { Schools Division Levels respectively }\end{array}$ & & \\
\hline a. Conduct monitoring & 3.82 & Often Observed \\
\hline b. Provide technical assistance & 4.06 & Often Observed \\
\hline c. Gather best practices and feedback & 4.29 & Always Observed \\
\hline Monitoring ranges from daily monitoring of & & \\
\hline a. Teacher attendance & 4.53 & Always Observed \\
\hline b. Punctuality & 4.53 & Always Observed \\
\hline c. Classroom preparation & 4.35 & Always Observed \\
\hline d. Curriculum implementation & 4.82 & Always Observed \\
\hline e. Child-teacher interactions & & Always Observed \\
\hline$\quad$ Average Mean & $\mathbf{4 . 2 8}$ & Always Observed \\
\hline
\end{tabular}

The table shows that in terms of monitoring and evaluation for the standard of delivery of Kindergarten services the teachers always observed that their Quality Assurance and the School Governance and Operations Divisions at the Region and Schools Division levels respectively gathers best practices and feedback. In addition, daily monitoring such as teacher's attendance, punctuality, classroom preparation, curriculum implementation, and child-teacher interactions are noted as always observed.

Whereas, often observed is noted in a teacher-student ratio which is ideally prescribed to be as 1:25 teacher-pupil ratio and classroom pupil ratio, monitoring and providing technical assistance which is conducted respectively by the Quality Assurance and the School Governance and Operations Divisions at the Region and Schools Division levels.

Table 18. Encountered Problems/Constraints

\begin{tabular}{|c|c|c|}
\hline Problems Encountered & Mean & Description \\
\hline 1. Large class ( more than 20 pupils per class) & 3.76 & Great Extent \\
\hline 2. Inadequate facilities & 3.35 & Great Extent \\
\hline 3. Inadequate playground space and equipment & 3.53 & Great Extent \\
\hline 4. Inadequate instructional materials & 3.24 & Moderate Extent \\
\hline 5. Inadequate classroom space & 3.47 & Great Extent \\
\hline 6. Lack of funds & 3.24 & Moderate Extent \\
\hline 7. Limited qualified teachers to teach & 2.53 & Moderate Extent \\
\hline 8. Problems met with the parents & 2.76 & Moderate Extent \\
\hline 9. Problems met with the children & 2.59 & Moderate Extent \\
\hline 10. Problems met with the administrators & 2.41 & Moderate Extent \\
\hline Average Mean & 3.09 & Moderate Extent \\
\hline
\end{tabular}

Table 18 reveals that teachers respondents in terms of problems encountered are a great extent such as large class (more than 20 pupils per class); inadequate facilities; inadequate playground space and equipment; and inadequate classroom space. Moderately extent such as inadequate instructional materials; lack of funds; limited qualified teachers to teach; problems met with the parents; problems met with the children; and problems met with the administrators.

The interventions made to get Across the Problems, upon informal interviews conducted by the researcher, in solution to the overcrowded class, most schools do shifting of classes or six (6) hours per day of sessions just to comply with the ideal class ratio. In terms of insufficient instructional materials, most of the teachers used their expenses from their pockets just to provide the needs of their learners. Regular Parent-Teacher Association meeting is conducted to address classroom needs and developmental growth of their pupils. Parents and stockholders helped the school in providing needs to its great extent. 


\section{Test of Significant Relationship}

The table shows the significant relationships between the respondent's perceptions of the implementation of Omnibus policy on kindergarten education program when grouped according to their profile using Pearson's Chi-square $\mathrm{C}$ - test at 0.05 level of significance.

As revealed in the table, the significance $\mathrm{C}$ - values for profile age, civil status, educational attainment, position, years of teaching early childhood education, and training attended in ECE, were greater than 0.05 . The null hypothesis is accepted. There is no significant relationship between the respondent's perceptions of the implementation of Omnibus policy on kindergarten education program when grouped according to their profile age, civil status, educational attainment, position, years of teaching early childhood education, and training attended in ECE.

Table 19. Significant Relationships between the Respondent's Perceptions of the Implementation of Omnibus Policy on Kindergarten Education Program and Their Profile

\begin{tabular}{|c|c|c|c|c|}
\hline Profile & $\begin{array}{c}\text { Significance Pearson's } \\
\text { Chi-square C }\end{array}$ & Analysis & Decision & Remarks \\
\hline Age & .171 & $\mathrm{C}>.05$ & $\begin{array}{l}\text { Accept } \\
\text { Ho }\end{array}$ & Not Significant \\
\hline Sex & $\begin{array}{l}\text { No Statistics are } \\
\text { computed }\end{array}$ & & & $\begin{array}{l}\text { Sex is Constant (All } \\
\text { are Female) }\end{array}$ \\
\hline Civil Status & .873 & $\mathrm{C}>.05$ & $\begin{array}{c}\text { Accept } \\
\text { Ho }\end{array}$ & Not Significant \\
\hline Educational Attainment & .208 & $\mathrm{C}>.05$ & $\begin{array}{c}\text { Accept } \\
\text { Ho }\end{array}$ & Not Significant \\
\hline Position & .984 & $\mathrm{C}>.05$ & $\begin{array}{l}\text { Accept } \\
\text { Ho }\end{array}$ & Not Significant \\
\hline Nature of Appointment & $\begin{array}{l}\text { No Statistics are } \\
\text { computed }\end{array}$ & & & $\begin{array}{c}\text { Nature of Appointment } \\
\text { is Constant } \\
\text { (All are Regular) }\end{array}$ \\
\hline $\begin{array}{l}\text { Years of Teaching Early } \\
\text { Childhood Education }\end{array}$ & .171 & $C>.05$ & $\begin{array}{c}\text { Accept } \\
\text { Ho }\end{array}$ & Not Significant \\
\hline Eligibility & $\begin{array}{l}\text { No Statistics are } \\
\text { computed }\end{array}$ & & & $\begin{array}{l}\text { Eligibility is Constant } \\
\text { (All are LET Passers) }\end{array}$ \\
\hline $\begin{array}{l}\text { Training Attended in Early } \\
\text { Childhood Education }\end{array}$ &, 873 & $\mathrm{C}>.05$ & $\begin{array}{c}\text { Accept } \\
\text { Ho }\end{array}$ & Not Significant \\
\hline
\end{tabular}

*Significance at 0.05

This indicates that age, civil status, educational attainment, position, years of teaching early childhood education, and training attended in ECE are the profile of the respondents that were considered do not influence their perceptions on the implementation of Omnibus policy on kindergarten education program. For the rest of the profile, statistics could not be established because they are constant.

\section{Test of Significant Difference}

The table shows the significant difference between the respondent's perceptions of the implementation of Omnibus policy on kindergarten education program when grouped according to their profile using Analysis of Variance (ANOVA) F - test at 0.05 level of significance.

Table 20. Significant Difference between the Respondent's Perceptions on the Implementation on Omnibus Policy on Kindergarten Education Program when grouped according to Their Profile

\begin{tabular}{|c|c|c|c|c|}
\hline \multicolumn{1}{|c|}{ Profile } & $\begin{array}{c}\text { Significance } \\
\text { F }\end{array}$ & Analysis & Decision & Remarks \\
\hline Age & .225 & F $>.05$ & $\begin{array}{c}\text { Accept } \\
\text { Ho }\end{array}$ & Not Significant \\
\hline
\end{tabular}




\begin{tabular}{|c|c|c|c|c|}
\hline Sex & No Statistics are computed & & & $\begin{array}{c}\text { Sex is Constant (All are } \\
\text { Female) }\end{array}$ \\
\hline Civil Status & .976 & $\mathrm{~F}>.05$ & $\begin{array}{c}\text { Accept } \\
\text { Ho }\end{array}$ & Not Significant \\
\hline Educational Attainment & .030 & $\mathrm{~F}<.05$ & $\begin{array}{c}\text { Reject } \\
\text { Ho }\end{array}$ & Significant \\
\hline Position & 0.75 & $\mathrm{~F}>.05$ & $\begin{array}{c}\text { Accept } \\
\text { Ho }\end{array}$ & Not Significant \\
\hline Nature of Appointment & No Statistics are computed & & & $\begin{array}{c}\text { Nature of Appointment } \\
\text { is Constant } \\
\text { (All are Regular) }\end{array}$ \\
\hline $\begin{array}{l}\text { Years of Teaching Early } \\
\text { Childhood Education }\end{array}$ & .266 & $\mathrm{~F}>.05$ & $\begin{array}{c}\text { Accept } \\
\text { Ho }\end{array}$ & Not Significant \\
\hline Eligibility & No Statistics are computed & & & $\begin{array}{l}\text { Eligibility is Constant } \\
\text { (All are LET Passers) }\end{array}$ \\
\hline $\begin{array}{l}\text { Training Attended in } \\
\text { Early Childhood } \\
\text { Education }\end{array}$ & .976 & $\mathrm{~F}>.05$ & $\begin{array}{c}\text { Accept } \\
\text { Ho }\end{array}$ & Not Significant \\
\hline
\end{tabular}

$* 0.05$ level of significance

As revealed in the table, the significance $\mathrm{F}$ - values for profile age, civil status, position, years of teaching early childhood education, and training attended in ECE, were greater than 0.05 . The null hypothesis is accepted. There is no significant difference between the respondent's perceptions of the implementation of Omnibus policy on kindergarten education program when grouped according to their profile age, civil status, position, years of teaching early childhood education, and training attended in ECE.

This indicates that age, civil status, position, years of teaching early childhood education, and training attended in ECE are the profile of the respondents that were considered not to affect their perceptions on the implementation of Omnibus policy on kindergarten education program.

For the respondent's educational attainment, the significance c- value was less than 0.05 . The null hypothesis is rejected. There is a significant difference between the respondent's perceptions of the implementation of Omnibus policy on kindergarten education program when grouped according to their profile educational attainment. Hence, the educational attainment of the respondents affects their perceptions of the implementation of Omnibus policy on kindergarten education program particularly those who are on the post-graduate studies with the highest mean perceptions followed by those who are Bachelor's degree holders. For the rest of the profile, statistics could not be established because they are constant.

\section{CONCLUSION AND RECOMMENDATION}

Based on the findings, in terms of implementation on the areas of the Omnibus Policy of Kindergarten Education, Assessment, Instruction, and Monitoring and Evaluation got the highest rating as always observed, whereas, Learning resources and instructional materials, and Learning space and environment were felt the same but of lower weighted mean. Hence, it is highly remarkable that inadequate play area and equipment found to be the most serious concern in the implementation of the Kindergarten program, and Information and Technology (ICT).

Constructivism approaches in the teaching-learning process found to be the least observed on Instruction specifically on Individualized instruction in 3Rs, simple experimentation for better concept formation among young learners, and educational field trips for hands-on learning. Assessment of learners has the highest weighted mean as always observed by the respondents, but there is a need to enhance the use anecdotal record and daily progress report log of each child as these are the primary bases of the teacher in the Kindergarten Progress Report Checklist every quarter. Large class, inadequate learning facilities, inadequate playground and space and equipment, and inadequate classroom space found as problems to a great extent by the teacher respondents. 
This study also concluded that teachers often observed their instructions such as Dramatic Play/ Housekeeping Area, Simple experiments, Individualized instruction in 3Rs, Uses of modern technology, and Outdoor Play for Physical Development. Furthermore, Educational trips, Simple experiments, and Outdoor play equipment were the least felt often observed as expected from public schools due to financial constraints. In addition, an Anecdotal record and Daily log of pupil's progress were posted with the least means. It is also note-taking that there are insufficient learners materials such as wordless picture books, concepts books, and board books that need to be provided. Much more so with sand and water play, and clay dough for sensory-motor development of young learners. No significant relationships found between the respondents' profile and implementation of the Omnibus Policy of Kindergarten, whereas, educational attainment of respondents has a significant difference in the implementation of the said policy. Educational attainment of the respondents affects their perceptions on the implementation of Omnibus policy on kindergarten education program particularly those who are on the post-graduate studies with the highest mean perceptions followed by those who are Bachelor's degree holders. Therefore, those teachers who attained the highest educational attainment have a clearer and better understanding of the implementing rules set by the omnibus policy.

In light of the findings and conclusions, the researchers propose the following recommendations for implementation: (1) National and international training may be attended regularly throughout the school year to ensure constant upgrading of ECE teacher skills and knowledge. Thus, making ECE teachers more competent in their field of endeavor; (2) School heads shall organize and monitor Learning Action Cells for all $\mathrm{K}$ to 3 teachers as a venue for continuous and cost-effective inservice training and teacher development. Trained Kindergarten teachers are encouraged to initiate and facilitate these collaborative learning sessions with other Kindergarten teachers; (3) Kindergarten teachers are encouraged to pursue continuous professional development by attending teacher-training programs, seminars, and/or conferences on areas such as but not limited to: developmentally appropriate practices, early intervention, child growth and development, early language, literacy, and numeracy (ELLN), Mother Tongue proficiency, and best practices in MTB-MLE implementation; (4) The school administrator may procure additional ICT resources for teachers' utilization through request or resolution from benevolent General Parent-Teachers Association (GPTA) and through their Maintenance and Other Operating Expenses or MOOE to enhance their teaching methodologies (technology-based approach), thus, improving the knowledge and skills of their pupils. Furthermore, the school should also regularly send the teachers in highly relevant seminars/workshops to upgrade their knowledge with regards to a technology-based approach in teaching. They should acquire other software which could help in the teaching and learning of pupils; (5) Play area may also be given emphasis and provided by the school authorities to be utilized by their pupils such as balance beam, swing, seesaw, monkey bars, simple obstacles, slides sand and water play equipment since play is essential and one of the medium of learning and communication and development of psychomotor skills for the kindergarten pupils; (6) The local government unit and the Department of Education, City Schools Division of Dasmariñas may allocate funds for the constructions of new school buildings and facilities to comply with the ideal classroom size and purchase necessary equipments for pupils use as this may perceived vital and have contributory factors for pupils' development and learning; (7) Since the researcher observed that teacher-pupil ratio is far different compared to the prescribed ideal ratio which is 1:25, it is perceived that for quality instructions, class size for ECE classes should be limited or reduced. Therefore, the Department of Education, City Schools Division of Dasmariñas should open up job opportunities in order to address the need for a lack of teachers to handle ECE classroom. If a regular item is not possible, the local or city government unit of Dasmariñas should allocate funds as a means of remuneration for contractual or local school board (LSB) position teachers, thus, preventing a type of classrooms; (8) There should be a modification and enhancement on instructions such as Dramatic Play/ Housekeeping Area, Simple experiments, Individualized instruction in 3Rs, and Outdoor Play for Physical Development. Educational field trips should be emphasized since kindergarten learners are perceived to be exploratory learners; (9) The use of anecdotal record and daily progress report log of each child should be enhanced because these are the primary bases of the teacher in the Kindergarten Progress Report Checklist and of modifying their classroom instruction, and lastly; (10) The school administrators may procure learner's materials such as wordless picture books, concepts books and board books. Much more so with sand and water play, and clay dough for sensorymotor development of young learners. Instructional materials that are provided to Kindergarten learners 
should be well-chosen, fit for purpose, and safe to use and manipulate. Materials should be stimulating, lightweight, and durable as well. All these instructional materials should be properly organized in the Kindergarten classroom to maximize their utility. Teachers should also take time to introduce how materials should be used and cared for by the learners.

\section{REFERENCES}

Bautista, A. (2012) Teacher's conception about learning and instructions. Journal of Curriculum Studies, Society of education

Baligod M. B.. (2012). "The Performance of Grade One Pupils with or without Pre-Elementary Education" Unpublish Masteral Thesis, Cagayan Colleges of Tuguegarao, Cagayan.

Bruce, T. (2014). Developing learning in early childhood. London: Paul Chapman

Brown A. B. (2016). Nursery Kindergarten Education, New York: Mac0-Graw-Hill Book Co., Inc., 2016

Carini, P. (2015). "Building A Curriculum For Young Children From an Experimental Based" Young Children Journal of the NAEYC, pp. 14-18.

Curtis, A and O'Hagan. M. (2013). Care and education in early childhood: A student's guide to theory and practice. London: Routledge Falmer.

DECS Order No. 60, s. 1993.

DepEd Order No. 12, s. 2012, Guidelines on Hiring and Deployment of Kindergarten Teachers.

DepEd Oder No. 7, series of 2015, Hiring Guidelines for Teachers for the School Year 2019-2020

DepEd Order No. 9, series of 2016, Reinforcement of DepEd Order Nos. 7 and 22, series of 2015 as the Hiring Guidelines for Kindergarten to Grade 10 Teaching Positions

Dowling, M. (2013). Young children's personal social and emotional development. London: Paul Chapman.

David Elkind. (2014). "What's Nest? Remedial Pre-School? The Educator's Digest. p. 9

Espedido, A. B. (2016) "Kindegarten Education Perspective. The Modern Teachers. Vol. XXX 14, No. 2.

Estolas J. \& Nunez D. (2014). Pre-School Education in the Philippines. (Quezon City, The Navotas Press,), p. 27

Elaine Wood, (2013), In search of the rainbow: pathways to quality in large-scale programmes for young disadvantage children. The Hague Foundation.

Elkind, E. (2014). "What's Nest? Remedial Pre-School? The Educator's Digest , (October 2014), p. 9

Finch, S. (2013). Setting up a day nursery: A step-by-step guide. VOLCUF, London Lancashire Country Council

French, G. (2013). Supporting quality: Guidelines for best practice in early childhood services (2nd ed.). Dublin: Barnardos.

Hermann, M. (1983). Froebel's kindergarten and what it means. The Irish Monthly, 54(634), 201-209.

Hohmann, M. and Weikart, D. (2015). Educating young children. USA: The High/Scope Press.

Malaguzzi, L. (2016). The right to the environment. In Filipini, T. and V. Vecchi (eds.), The hundred languages of children: The exhibit. Reggio Emilia: Reggio Children

Luistro, A. A. (2016). DepEd Order No. 47, series of 2016 omnibus policy on kindergarten education, Department of Education, Philippines

Laevers, F. (2010). A process-oriented child follow-up system for young children. Leuven: Centre for Experiential Education

Malaguzzi, L. (2016). The right to the environment. In Filipini, T. and V. Vecchi (eds.), The hundred languages of children: The exhibit. Reggio Emilia: Reggio Children

National Council for Curriculum and Assessment. (2014). Towards a Framework for Early Learning. Dublin: National Council for Curriculum and Assessment.

Pangan, M S. (2012). Kindergarten education for Philippine schools.QQuezon City: Allied Printing and Binding Company, p.1.

Penn H. (2015). Understanding early childhood. Glasgow: Open University Press.

Ravalo, E. (2015), Setting Standards For pre-school Teachers, The Modern Teachers, Vol. LV, No. 3 p. 12

Reynolds, A, (2012). Success in early intervention: The Chicago child-parent centers. Nebraska: University of Nebraska Press

Rich, D. \& Drummond. J. (2014). Towards a curriculum that maters to children. Paper presented at the European Early Childhood Education Research Association's 16th Annual Conference, Democracy and culture in early childhood education, Reykjavik, Iceland, from Aug 30th - Sept $2^{\text {nd }}$

Solis M. F. (2012). "Pre-Primary Education in a must in Child Care", National Coordinating Center for the Development of the Children and Youth, (A Brochure).

Smith, P., Cowie, H. and Blades, M. (2013). Understanding children's development (4th ed.). UK: Blackwell Publishing. 
Stinson S.S. (2014). "Movement as Creative Interaction with the Child," Young Children, Journal of AEYC, September, pp. 47-53.

UNICEF (2018) Philippines (n.d.). "Early childhood care and development early learning. Providing a right start to learning and of life for all children" Makati: UNICEF.

UNESCO (2016). International Bureau of Education (IBE) Geneva, (Switzerland), Philippines Early Childhood Care and Education (ECCE) programmes. 